\title{
Perancangan Video Interaktif Profil Tim Arema Cronus 2016
}

\author{
Ramadhani Pratama Putra ${ }^{1}$, Faldi Hendrawan ${ }^{2}$, Nicholaus Wayong Kabelen ${ }^{3}$, Widya \\ Adhariyanty Rahayu ${ }^{4}$ \\ ${ }^{1,2,3}$ Desain Komunikasi Visual, ${ }^{4}$ Informatika \\ 11 ramadhaniputra44@gmail.com, ${ }^{2}$ faldikobenasia@gmail.com, ${ }^{3}$ wayongkabelen@ gmail.com, \\ ${ }^{4}$ widyariyanty@gmail.com
}

\begin{abstract}
ABSTRAK
Sepakbola adalah olahraga yang sangat populer di seluruh dunia termasuk di Indonesia. Arema Cronus merupakan salah satu tim sepakbola Indonesia yang dikelola secara profesional dan memiliki penggemar dengan jumlah cukup besar. Kurangnya informasi secara mendalam tentang profil tim pelatih dan pemain Arema Cronus membuat para penggemar sedikit kesusahan dalam mencari informasi tersebut. Perancangan video interaktif dipilih untuk memudahkan penggemar mencari informasi profil tim Arema Cronus sekaligus menjadi terobosan terbaru penyampaian informasi berupa video interaktif melalui web portal Youtube.

Untuk mendukung penyelesaian penelitian digunakan beberapa metodologi yaitu kajian pustaka yang dilakukan dengan membaca buku untuk mempelajari teori pengambilan gambar sampai proses pengeditan video. Metodelogi wawancara dengan narasumber untuk mendapatkan informasi yang benar. Observasi dengan pengamatan langsung saat Arema Cronus menggelar latihan atau pertandingan. Metode dokumentasi dengan mengumpulkan data berupa foto atau video. Beberapa tahapan untuk proses produksi yaitu pengambilan objek foto atau video, editing foto, membuat layout dengan CorelDraw, editing video menggunakan Adobe Premiere dan mengunggah video ke portal Youtube.

Kesimpulan dari pembahasan ini adalah merancang video interaktif sebagai media pengenalaman profil tim Arema Cronus dengan tampilan antar muka yang mudah dipahami, dapat diakses dimanapun dan kapanpun. Saran perancangan ini adalah kedapannya ada yang membuat video interaktif ini dalam versi offline.
\end{abstract}

Kata kunci: Arema Cronus, Video, Interaktif, Profil, 2016

\begin{abstract}
Football is a sport that is very popular throughout the world, including in Indonesia. Arema Cronus is one of the Indonesian football team which is professionally managed and has big amount of fans. The lack of in-depth information about the profile of the team, coaches and players of Arema Cronus make the fans get a little trouble in finding such information. Designing interactive video is selected to facilitate the search for profile information of Arema Cronus team as well as the latest breakthrough in the delivery of information in the form of interactive video through a web portal Youtube.

To support the completion of the study used several methodologies namely literature review conducted by reading a book to learn the theory of shooting to the editing process. Interviews methodology with sources to get the correct information. Observations by direct observation when Arema Cronus held a practice or game. Methods of documentation is used to collect data such as photos or videos. Several stages of the production process those are the object taking photos or video, editing photos, creating layouts with CorelDraw, using Adobe Premiere video editing and uploading videos to Youtube portal.

The conclusion of this discussion was to design interactive video as a introduction media of the Arema Cronus profile displayed interface to make it easy to understand, accessible everywhere and everytime. For the future, the design is suggested to have interactive video in the offline version.
\end{abstract}

Keywords: Arema Cronus, Video, Interactive, Profile, 2016 


\section{PENDAHULUAN}

FIFA (Federation International the Football Association) merupakan organisasi yang menaungi sepakbola di negara-negara yang menjadi anggota FIFA, termasuk Indonesia. Didirikan pada tanggal 21 Mei 1904, FIFA bermarkas di Zurich, Swiss. Sepakbola adalah cabang olahraga yang dimainkan oleh dua regu, masing-masing regu terdiri dari sebelas pemain termasuk penjaga gawang. Sepakbola merupakan salah satu cabang olahraga yang digemari masyarakat Indonesia dan banyak dimainkan oleh seluruh lapisan masyarakat, baik itu anak-anak, remaja, dan orang tua. Dalam meningkatkan kemampuan pemain, perlu adanya organisasi sebagai tempat pembinaan. Organisasi tersebut biasa disebut dengan klub, dalam klub sepakbola perlu adanya manajemen organisasi untuk kelangsungan organisasi sepakbola tersebut.

Arema Cronus adalah salah satu organisasi dan perusahaan dibawah naungan PSSI (Persatuan Sepakbola Seluruh Indonesia) bergerak di bidang olahraga sepakbola yang berada di Kota Malang. Arema Cronus memiliki pelatih dan pemain berbakat dan profesional sehingga banyak dikenal masyarakat. Arema Cronus dahulu bernama Arema Malang adalah sebuah klub sepak bola yang bermarkas di Jalan Kertanegara No. 7 Malang. Arema didirikan pada tanggal 11 Agustus 1987 dan mempunyai julukan "Singo Edan". Stadion Kanjuruhan dan Stadion Gajayana menjadi home base dikala menggelar laga kandang. Prestasi Arema yang pernah diraih seperti juara Galatama (1992/1993), Divisi 1 Liga Indonesia 2004, COPA Indonesia 2005, COPA Indonesia 2006, Indonesia Super League (2009/2010), peringkat 2 Indonesia Super League (2010/2011), peringkat 2 Indonesia Super League (2012/2013), peringkat 2 Indonesia Super League (2010/2011).

Kurangnya informasi secara detail tentang data diri pelatih dan pemain membuat para penggemar kesusahan mencari informasi tersebut. Dalam hal ini video interaktif dipilih karena memberikan kemudahan pengguna dalam menentukan informasi yang diinginkan berdasarkan chapter dengan memilih menu telah disediakan. Video Interaktif tentunya akan memberikan pengematan waktu tanpa harus menonton secara keseluruhan. Video interaktif profil tim dan pelatih Arema Cronus 2016 mampu memberikan terobosan baru dalam memanfaatkan sosial media yang semakin berkembang. Dipilihnya video interaktif melalui web portal Youtube, karena nantinya profil tim dan pelatih Arema Cronus 2016 dikemas dalam bentuk video, maka media sosial Youtube sangat tepat digunakan karena informasi yang disampaikan mudah tersebar luas. Salah satu fitur Youtube yaitu anotasi akan memudahkan untuk memberikan pilihan menu di dalam video yang di unggah. Pengguna dapat menentukan ingin mendapatkan informasi dari sebuah video pada chapter tertentu dan tidak membuang banyak waktu untuk melihat video secara keseluruhan terlebih dahulu. 


\section{PEMBAHASAN}

\section{Perancangan}

Perancangan adalah kemampuan untuk membuat beberapa alternatif pemecahan masalah (Susanto, 2013:51). Perancangan adalah suatu sistem yang berlaku untuk segala jenis perancangan, dimana titik beratnya adalah melihat suatu persoalan tidak secara terpisah atau tersendiri, melainkan sebagai satu kesatuan, satu masalah dengan lainya yang saling berkaitan (Siregar, 2009:1). Multimedia interkatif merupakan alat atau sarana pembelajaran yang berisi materi, metode, batasan-batasan, dan cara mengevaluasi yang dirancang secara sistematis dan menarik untuk mencapai kompetensi/subkompetensi mata pelajaran yang diharapkan sesuai dengan tingkat kompesitasnya (Riyana, 2007:5)

Sedangkan menurut Tay adalah kombinasi teks, grafik, suara, animasi dan video, dengan kata lain melibatkan seluruh aktivitas indera. Selain itu pengguna mendapatkan keleluasaan dalam mengontrol sehingga disebut multimedia interaktif (Pramono, 2007:5). Winata (2013:17) menyebutkan fungsi multimedia interaktif yaitu suplemen, komplemen, substitusi.

\section{Desain}

Grapich, atau grafis dalam bahasa Indonesia, berasal dari bahasa Yunani Graphein yang berarti menulis atau menggambar. Sementara itu, istilah seni Grafis yaitu seni gambar dalam dua dimensi pada umumnya mencakup beberapa bentuk kegiatan, seperti menggambar, melukis, dan fotografi. Secara spesifik cakupan tadi terbatas pada karya yang dicetak atau karya seni yang dibuat untuk diperbanyak melalui proses cetak (Kusrianto, 2007:28)

Desain grafis adalah mempekerjakan berbagai elemen seperti marka, simbol, uraian verbal yang divisualisasikan lewat tipografi dan gambar, baik dengan teknik fotografi ataupun ilustrasi. Elemen-elemen tersebut diterapkan dalam dua fungsi perangkat visual dan perangkat komunikasi (Setiawan, 2011:11-12). Yoga (2013:19) menyebutkan prinsipprinsip desain yang harus diperhatikan dalam sebuah desain yaitu kesatuan, keseimbangan, proporsi, irama. Sedangkan Supriyono (2010:9) membagi elemen dasar grafis menjadi garis, bidang, warna, gelap terang, gestur, dan ukuran.

\section{Deskripsi Produk}

Produk ini berjudul "Video Interaktif Profil Tim Arema Cronus 2016", dengan format file MP4, frame rate $23.97 \mathrm{fps}$, beresolusi 1280* $1080 \mathrm{px}$, dengan durasi 15,39 menit. Alur kerangka digunakan untuk mempermudah dalam proses pembuatan video interaktif berdasarkan tahapan-tahapan yang diawali dengan video pembuka. Pada akhir waktu yang sudah ditentukan di dalam masing-masing video akan muncul menu yang dapat dipilih untuk menonton bagian mana yang ingin ditonton sebagai video interaktif. Sebagai halaman utama akan muncul empat menu pilihan, tiga diantaranya berdasarkan posisi pemain dan satu menu untuk pelatih. 
Tabel 1. Alur Kerangka

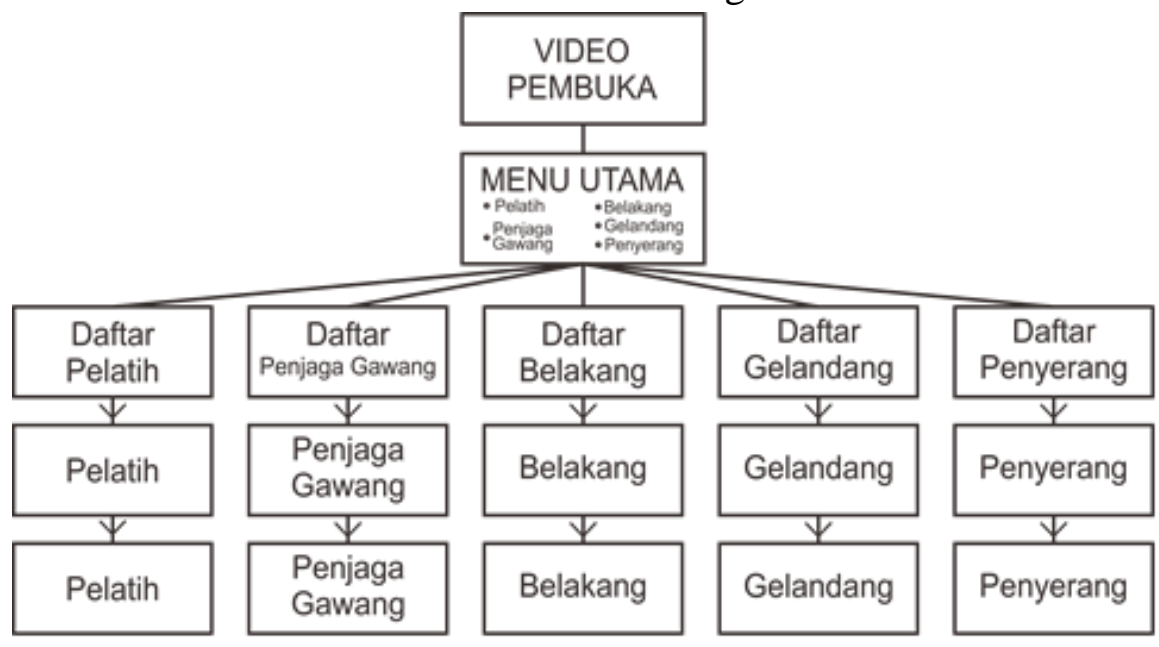

Berikut adalah storyline untuk video pembuka yang diawali dengan menampilkan balai Kota Malang hingga cuplikan pertandingan Arema.

Tabel 2. Storyline Video Pembuka

\begin{tabular}{|c|l|l|}
\hline No. & \multicolumn{1}{|c|}{ Visual } & \multicolumn{1}{|c|}{ Audio } \\
\hline 1 & & \\
\hline 2 & $\begin{array}{l}\text { Menampilkan balai Kota Malang disertai } \\
\text { Tugu }\end{array}$ & \\
\hline 3 & $\begin{array}{l}\text { Menampilkan halaman depan dan } \\
\text { berbagai sudut di kantor Arema yang } \\
\text { menjadi tempat untuk kegiatan dari } \\
\text { manajemen Arema. }\end{array}$ & \\
\hline 4 & $\begin{array}{l}\text { Menampilkan suasana pertandingan di } \\
\text { Stadion Kanjuruhan saat Arema } \\
\text { bertanding. }\end{array}$ \\
\hline
\end{tabular}

Berikut ini merupakan storyline pada bagian menu. Diawali dengan video pembuka, selanjutnya akan masuk pada menu utama yang menampilkan lima menu berdasarkan posisi yaitu pelatih, penjawaga gawang, bertahan, gelandang dan penyerang. Dari masing-masing menu akan menuju menu bagian posisi. Menu ini akan menampilkan daftar pelatih atau pemain sesuai dengan posisi dari menu pelatih hingga menu penyerang. 80 
Tabel 3. Storyline Menu Utama

\begin{tabular}{|c|l|l|}
\hline No. & \multicolumn{1}{|c|}{ Visual } & \multicolumn{1}{|c|}{ Audio } \\
\hline 1 & $\begin{array}{l}\text { Menampilkan menu utama yang didalamnya terdapat } \\
\text { lima menu berdasarkan posisi yaitu pelatih, penjaga } \\
\text { gawang, bertahan, gelandang dan penyerang. }\end{array}$ & $\begin{array}{l}\text { Backsound "Corporate } \\
\text { Background Music" }\end{array}$ \\
\hline 2 & $\begin{array}{l}\text { Setiap menu pada menu utama akan masuk pada } \\
\text { menu yang lebih detail yaitu menu berdasarkan } \\
\text { posisi. Dimenu ini akan menampilkan daftar nama } \\
\text { dan foto pelatih atau pemain. }\end{array}$ & $\begin{array}{l}\text { Backsound "Corporate } \\
\text { Background Music" }\end{array}$ \\
\hline 3 & $\begin{array}{l}\text { Pada masing-masing halaman informasi pelatih atau } \\
\text { pemain, akan menampilkan cuplikan video singkat } \\
\text { dan informasi data diri pelatih atau pemain Arema } \\
\text { Cronus. Akan tersedia juga dua menu untuk kembali } \\
\text { ke menu utama atau berpindah ke halaman profil } \\
\text { pelatih atau pemain selanjutnya. }\end{array}$ & $\begin{array}{l}\text { Backsound "Corporate } \\
\text { Background Music" }\end{array}$ \\
\hline
\end{tabular}

Sebelum melakukan proses pembuatan video interaktif ini akan terlebih dahulu dibuat storyboard yang terbagi menjadi tiga kolom diantaranya berupa kolom teks, visualisasi, dan durasi. Storyboard akan berfungsi sebagai dasar data panduan dalam bentuk gambar guna menjadi acuan dalam proses pembuatan. Storyboard dapat dilihat pada tabel 4 . sebagai berikut:

Tabel 4. Storyboard

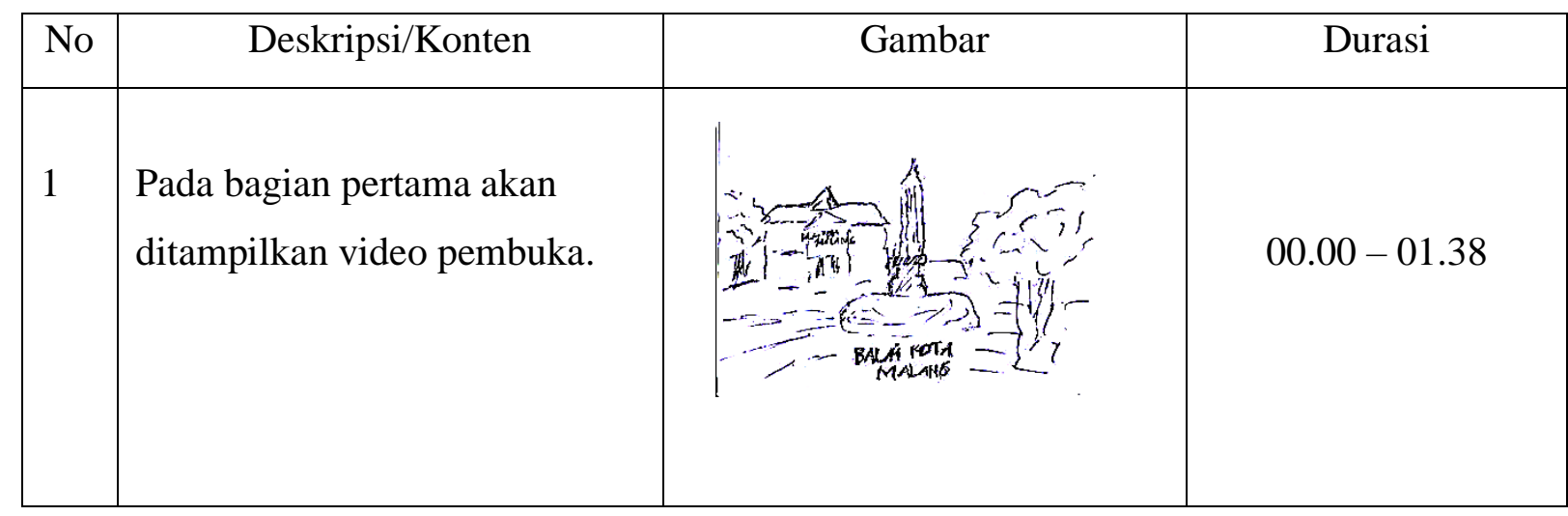




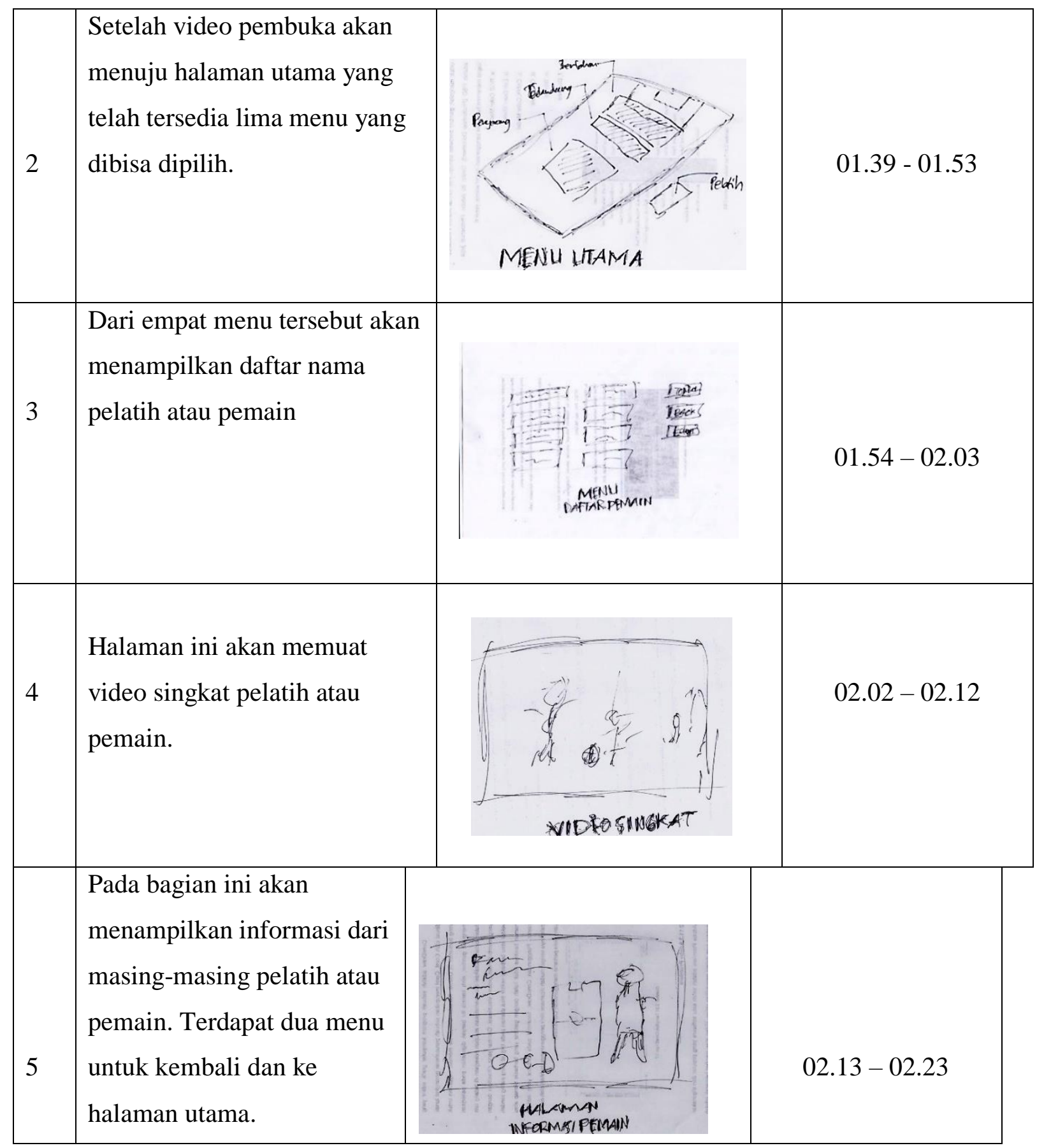




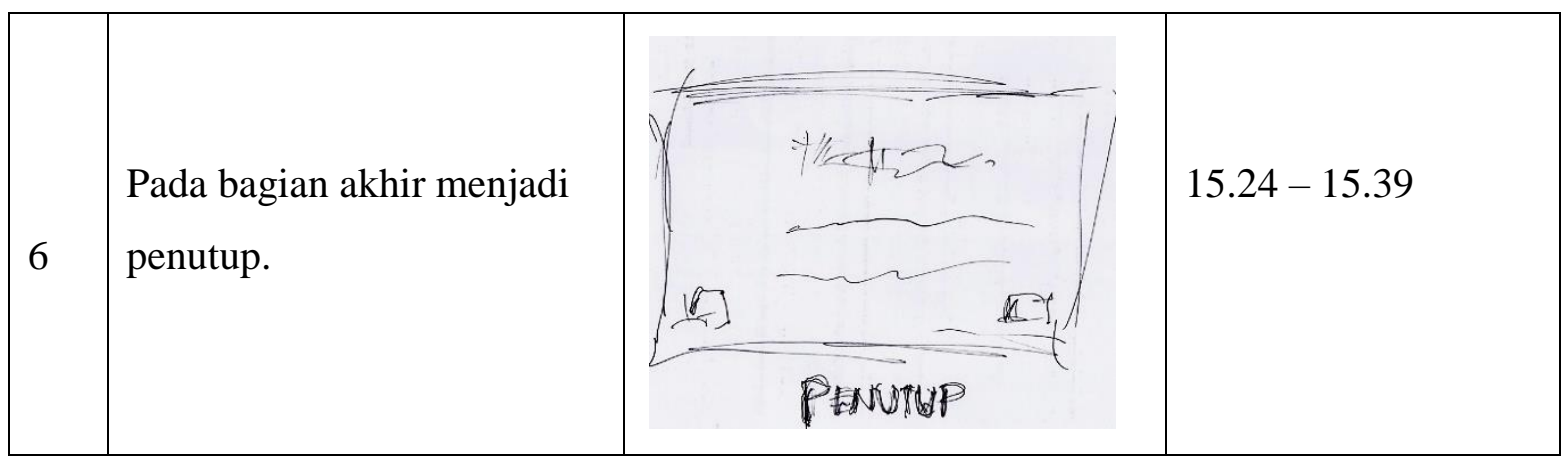

Pada perancangan video interaktif ini memiliki empat tahapan dalam proses produksi yaitu pengambilan gambar, editing gambar, layout, dan editing video. Tahap pengambilan gambar merupakan tahap awal dalam proses pembuatan video interaktif. Pengambilan gambar dilakukan saat tim Arema Cronus berlatih atau bertanding di Stadion Gajayana, Stadion Kanjuruhan dan dilapangan-lapangan yang menjadi alternatif untuk berlatih. Waktu untuk pengambilan gambar tidak ditentukan, hanya mengikuti jadwal agenda tim Arema Cronus menggelar latihan.

Sebelum proses pengambilan gambar persiapan yang dilakukan adalah memastikan peralatan yang akan digunakan. Menggunakan 2 kamera Nikon D200 dan Nikon D3100 dengan 2 lensa standart dan lensa tele untuk memudahkan pengambilan gambar jarak jauh, karena objek yang diambil merupakan objek bergerak.

Setelah proses pengambilan gambar, selanjutnya dilakukan pemilihan gambar sesuai kebutuhan. Karena kebutuhan akan gambar dengan objek pemain tunggal seluruh badan, maka harus dipastikan tidak ada objek lain yang menutupi area badan dari pemain.

Selanjutnya gambar yang sudah dipilih akan masuk proses editing menggunakan Adobe Photoshop CS6. Proses menggunakan software ini dilakukan untuk menyeleksi area badan pemain dan menghilangkan background yang tidak digunakan. Hasilnya adalah gambar pemain tunggal yang digunakan untuk proses layout di software CorelDraw. 


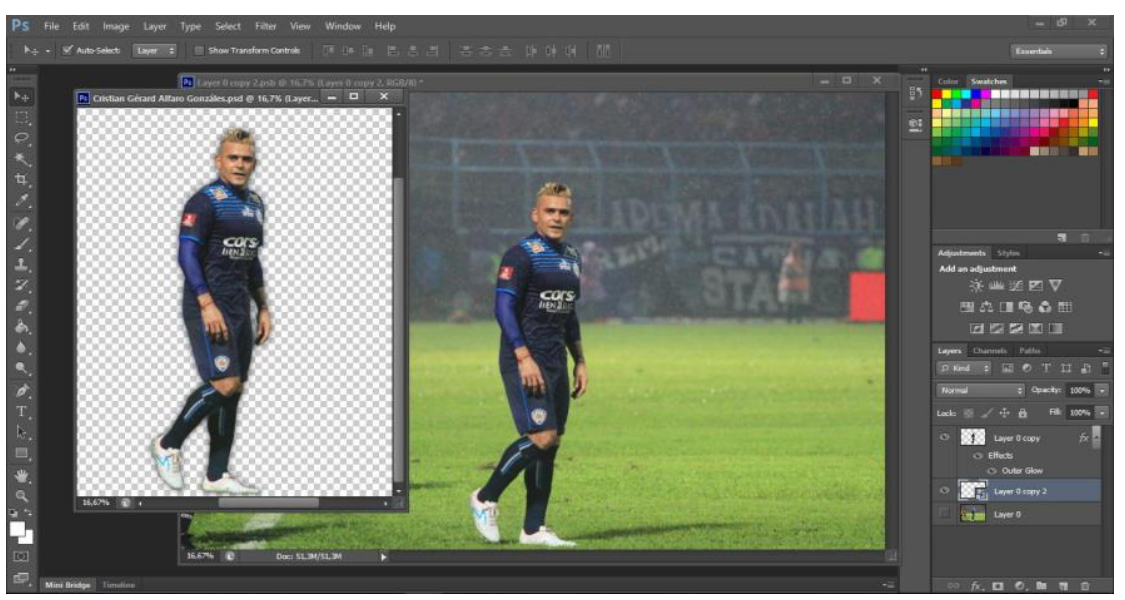

Gambar 1. Seleksi Gambar

Dalam video interaktif ini terdapat tombol-tombol menu untuk mengoprasikannya. Tombol menu dapat digunakan untuk memilih bagian informasi yang ingin ditampilkan tanpa harus melewati tahapan tertentu. Tema yang digunakan pada halaman menu utama disesuaikan dengan tema awal yang telah ditentukan yaitu bebentuk lapangan sepakbola dengan menampilkan beberapa posisi.

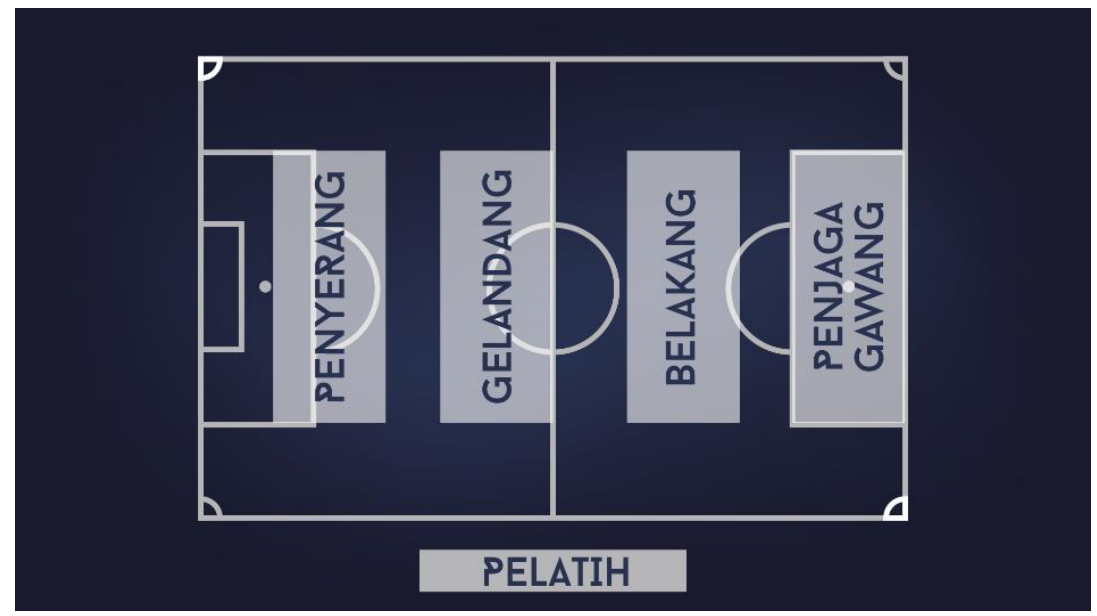

Gambar 2. Desain Menu Utama

Pada menu utama terdapat lima pilihan atau tombol yang tersedia, yaitu: Penyerang, Gelandang, Bertahan, Penjaga Gawang, dan Pelatih. Tombol-tombol tersebut ditentukan berdasarkan posisi dalam sepakbola.

Tombol tersebut bisa dipilih dengan menekan pada salah satu teks posisi. Terdapat tautan pada tombol tersebut untuk menuju halaman informasi yang telah dipilih. Masing- 
masing tombol akan menampilkan menu berbeda berdasarkan posisi dari pemain atau pelatih. Menu posisi pelatih ini diurutkan berdasarkan jabatan dari pelatih. Menampilkan foto dan nama untuk mempermudah pengguna dalam menavigasi.

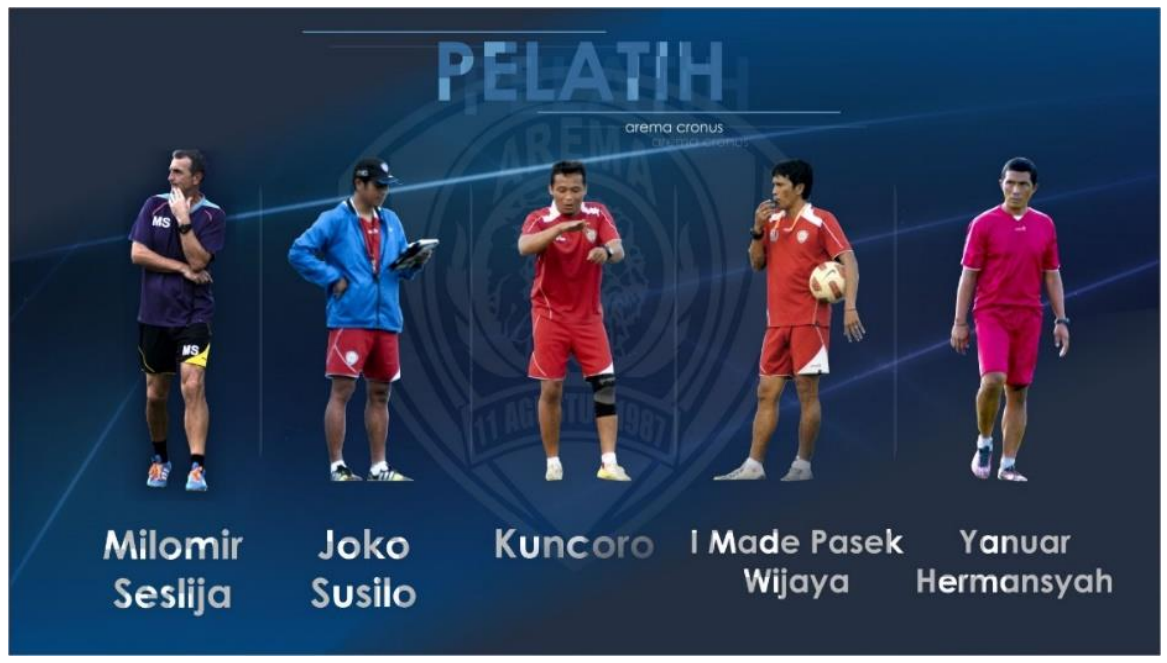

Gambar 3. Desain Menu Pelatih

Selanjutnya menu penjaga gawang. Menu ini berbeda dengan menu pelatih. Terdapat perbedaan pada penataan dari masing-masing pemain. Jika menu pelatih terlihat sejajar, untuk menu penjaga gawang menampilkan tata letak yang diurutkan berdasarkan pemain inti, susunan dari Kurnia Meiga, I Made Wardhana, Achmad Kurniawan dan Utam.

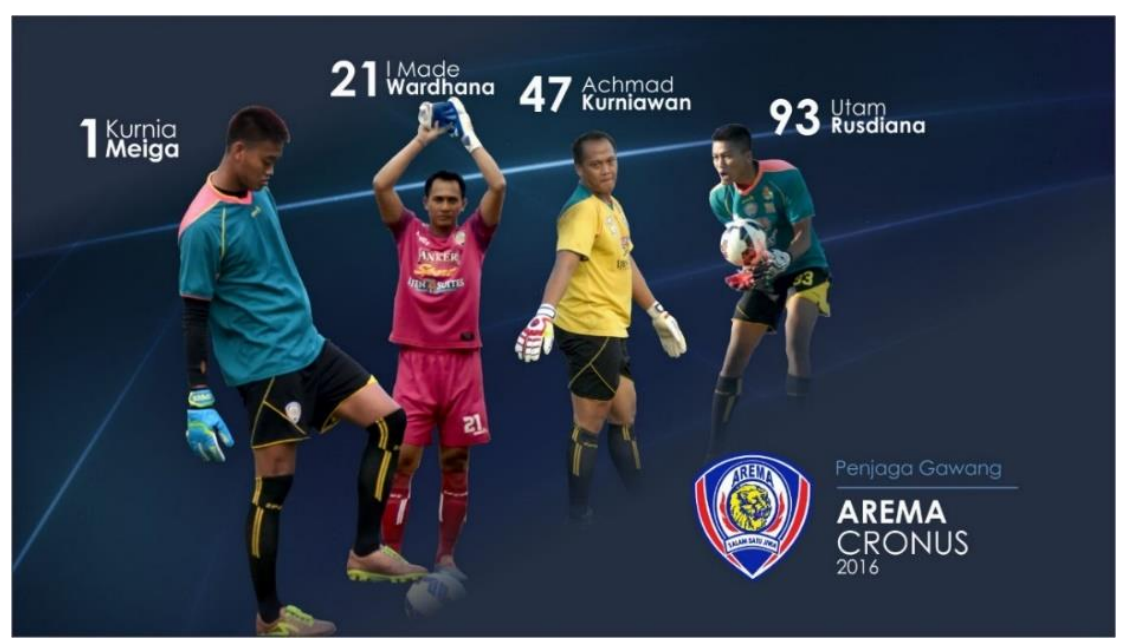

Gambar 4. Desain Menu Penjaga Gawang 
Menu selanjutnya adalah posisi belakang atau pemain bertahan. Penggunaan background biru dikombinasi dengan garis bercahaya pada setiap menu masih sama.

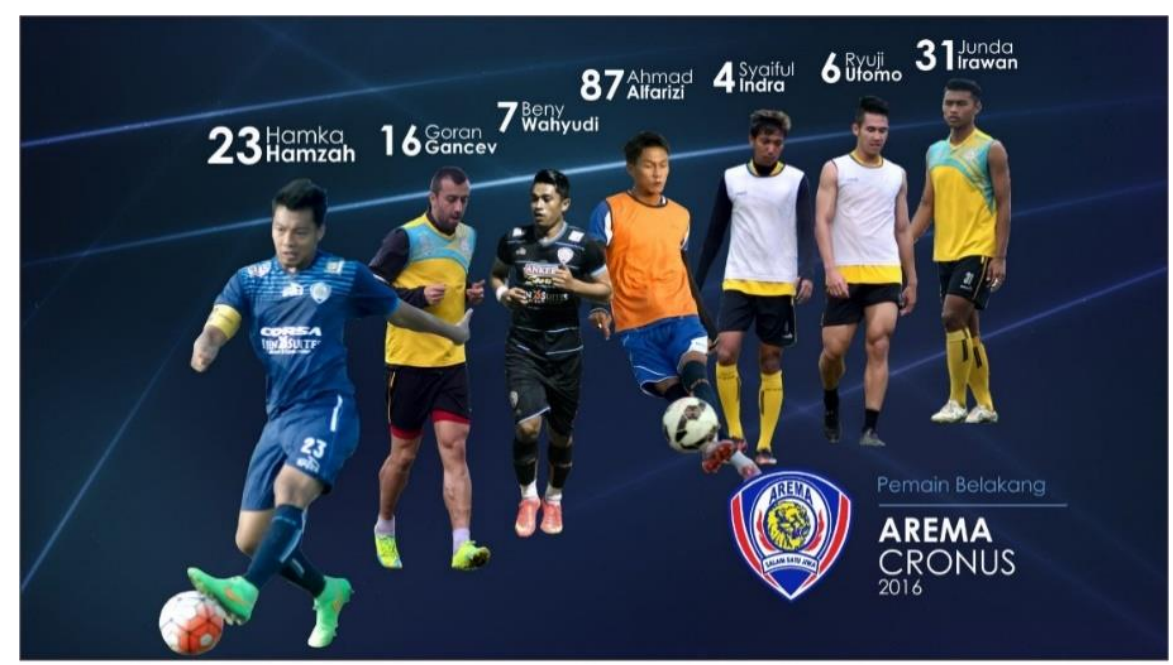

Gambar 5. Desain Menu Pemain Belakang

Tata letak menu pemain belakang dengan menu penjaga gawang memiliki kesamaan. Menampilkan berdasarkan pemain inti dimuali dari Hamka Hamzah, Goran Gancev, Beny Wahyudi, hingga pemain pelapis seperti Junda Irawan.

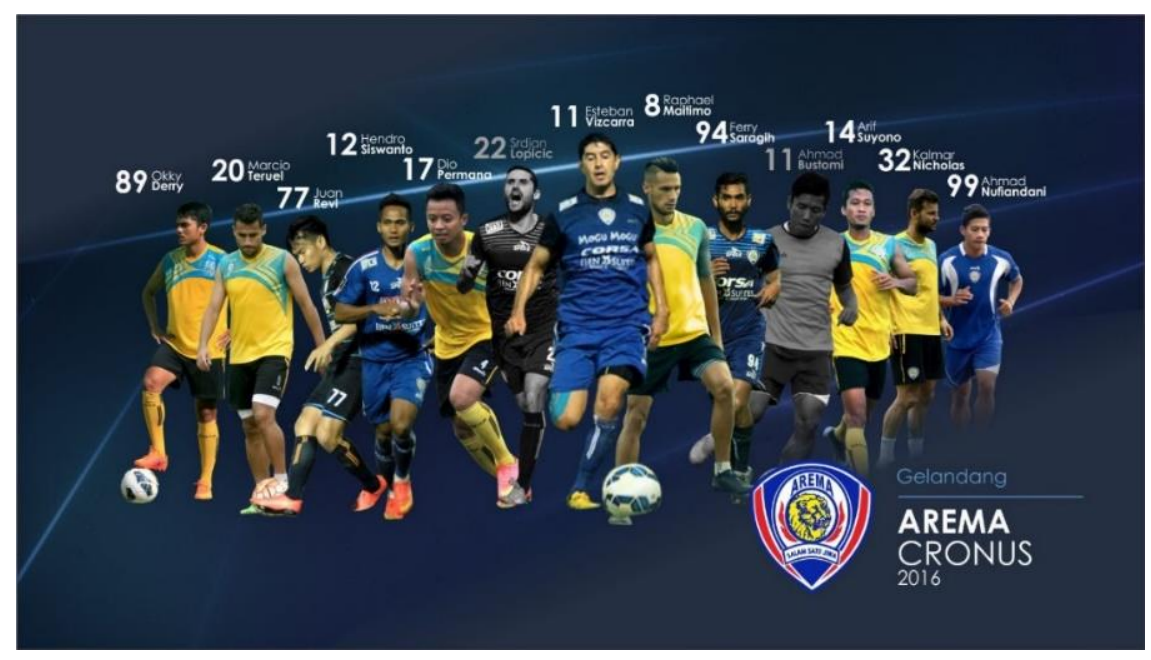

Gambar 6. Desain Menu Pemain Gelandang

Menu gelandang sedikit berbeda dengan menu sebelumnya yaitu penjaga gawang dan pemain belakang. Berdasarkan jumlah pemain gelandang yang lebih banyak dari posisi 
lainnya, memberikan tata letak berbeda agar semua pemain dapat terlihat. Terdapat dua pemain yaitu Srdan Lopicic dan Ahmad Bustomi terlihat berbeda dengan pemain lainnya, foto dengan mode grayscale menjelaskan bahwa kedua pemain tersebut tidak memperkuat Arema pada ajang turnamen Torabika Soccer Championship 2016.

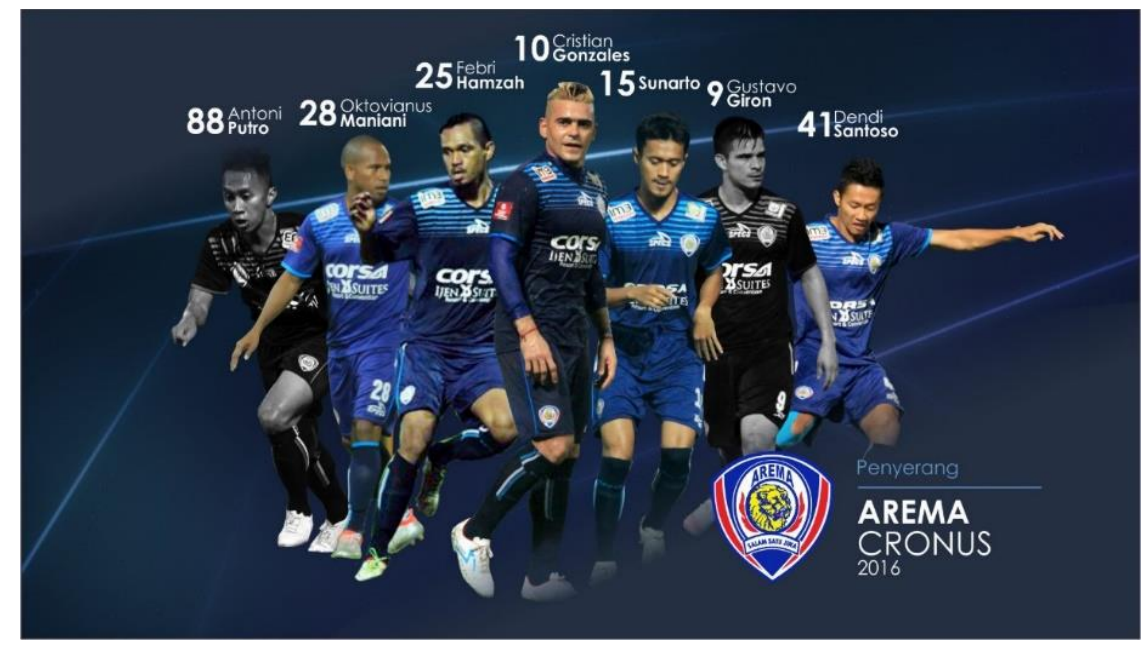

Gambar 7. Desain Menu Penyerang

Tidak jauh berbeda dengan menu-menu sebelumnya, menu pemain dengan posisi penyerang menampilkan tujuh pemain dan dua diantaranya yaitu Antoni Putro dan Gustavo Giron tidak membela Arema lagi. Menampilkan foto, nama, serta nomor punggung yang dipakai untuk mempermudah pengguna dalam menavigasi informasi yang dibutuhkan.

Setelah pengguna menentukan informasi yang ingin diterima melalui pilihan menu berdasarkan posisi, selanjutnya pengguna akan dibawa masuk pada informasi yang lebih lengkap. Disini penerima informasi akan mendapatkan sejumlah informasi yang mengenai data diri pemain atau pelatih seperti foto, nama lengkap, posisi, kelahiran, kebangsaan hingga karir dalam sepakbola. Berikut contoh tampilan profil salah satu pelatih Arema Cronus yaitu Milomir Seslija. 


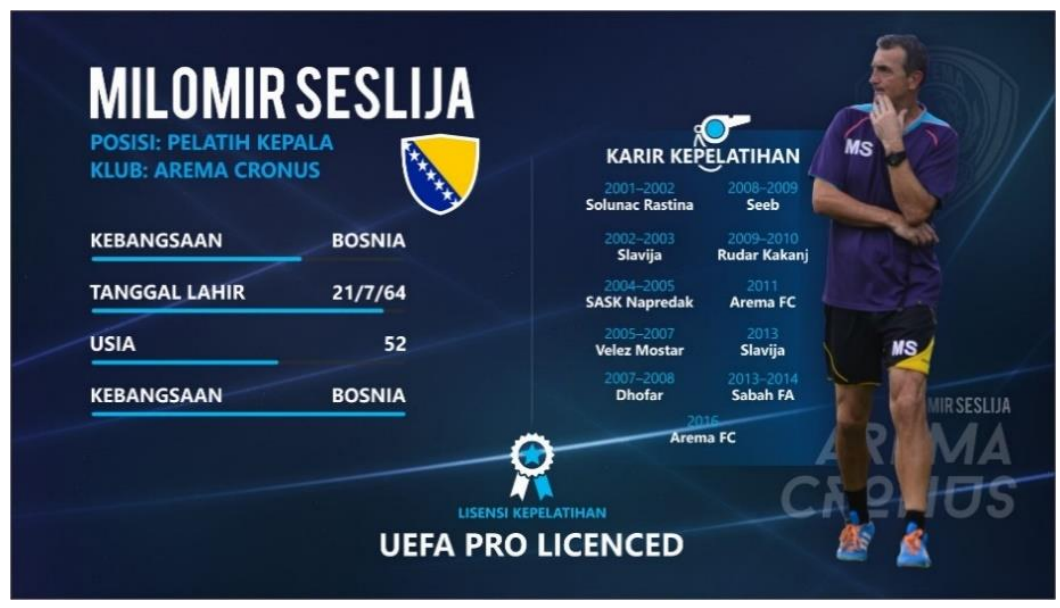

Gambar 8. Desain Tampilan Profil Pelatih

Penggunaan background biru dengan kombinasi garis bercahaya putih masih menjadi pilihan utama, dipilihnya background tersebut selain Arema memiliki warna khas biru, agar informasi berupa teks berwarna terang dan gambar dapat terlihat dengan jelas.

Informasi yang disampaikan terbagi menjadi dua yaitu data diri dan karir dalam sepakbola. Jika pelatih atau pemain memiliki legalitas, maka pada bagian bawah akan terlihat seperti Milomir Seslija yang memiliki lisensi UEFA Pro. Tampilan profil pemain memiliki layout serupa dengan pelatih, hanya terdapat perubahan pada teks karir kepelatihan menjadi karir klub serta penambahan nomor punggung yang dikenakan.

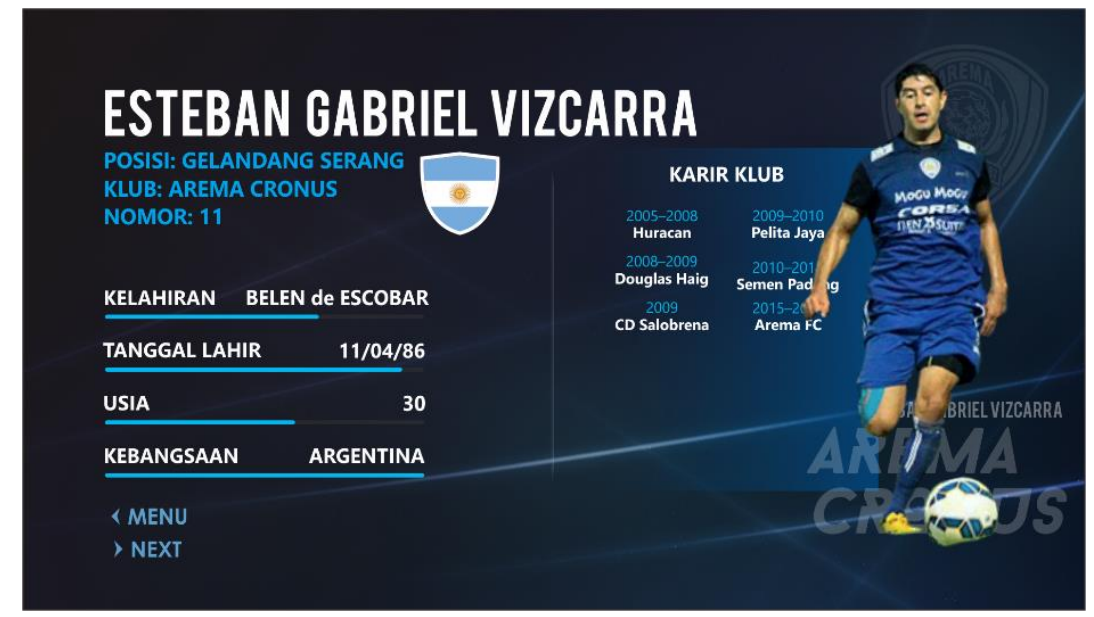

Gambar 9. Desain Tampilan Profil Pemain 
Proses selanjutnya membuat layout untuk menampilan informasi seputar profil tim pelatih dan pemain Arema Cronus. Dalam langkah ini menggunakan software CorelDraw X6 untuk membuat layout dan mengkombinasikan dengan gambar setiap pelatih atau pemain. Menentukan ukuran layout 1920px*1080px untuk menghasilkan gambar yang maksimal dan dapat terbaca dengan jelas informasi yang disampaikan nantinya. Background yang digunakan adalah berwarna biru gelap dengan kombinasi garis putih. Dipilihnya background gelap agar informasi berupa teks berwarna terang dapat terlihat jelas.

Proses layout ini dilakukan kepada seluruh pelatih dan pemain Arema Cronus secara individu. Informasi yang ditampilkan tidak memiliki kesamaan, mengingat setiap pelatih dan pemain memiliki perjalan karir yang berbeda.

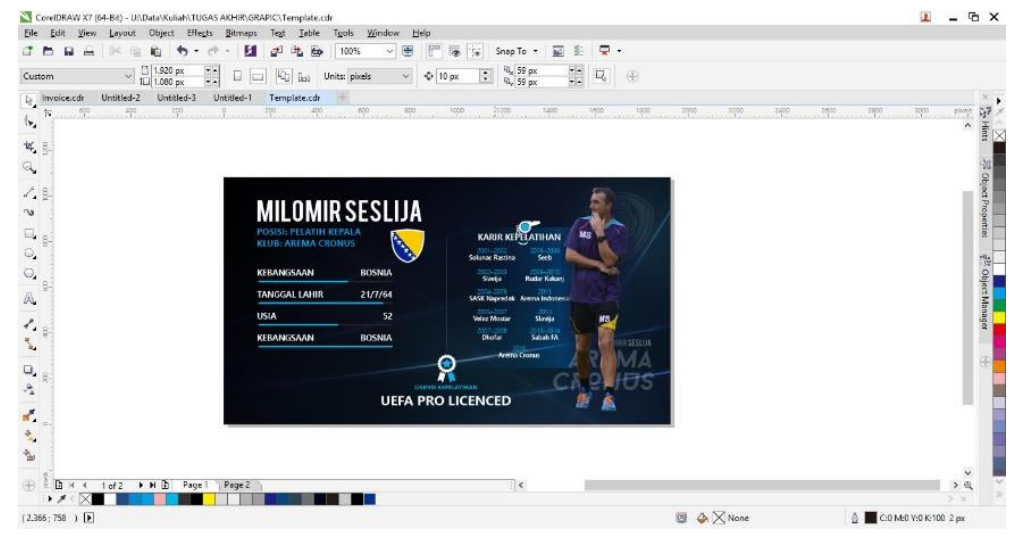

Gambar 10. Proses Pembuatan Layout

Pada pembuatan video interaktif tim pelatih dan pemain Arema Cronus ini terdapat beberapa tahapan editing untuk menyatuhkan informasi profil berupa gambar disusun sesuai dengan alur masing-masing durasi.

\section{Pengaturan Objek}

Langkah awal proses editing menggunakan software pengolah video Adobe Premiere CS6 adalah dengan mengatur halaman lembar kerja menyesuaikan dengan ukuran lembar kerja pada software CorelDraw agar hasil yang dimunculkan sesuai. Lembar kerja pada Adobe Premiere menggunakan Frame Size 1280h*1080v, Frame rate 23,97 frames/second dan menggunakan audio rate $48 \mathrm{kHz}$. 


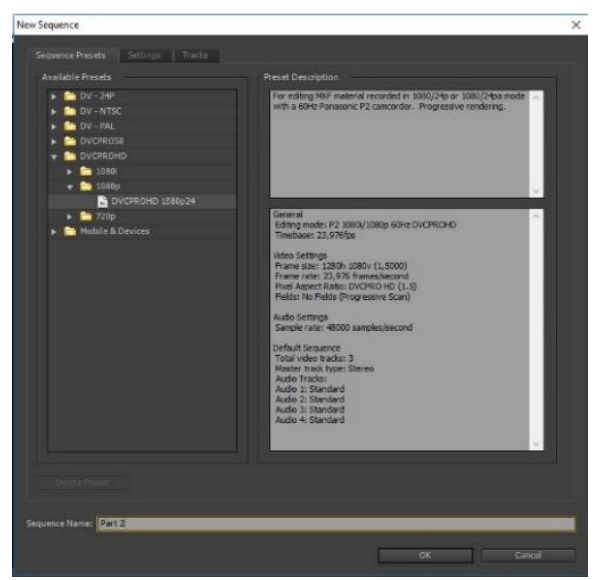

\section{Pengaturan Komposisi}

Gambar 11. Setting Projek

Tahap komposisi ini digunakan untuk mengabungkan beberapa gambar, video dan audio menjadi kesatuan kedalam software Adobe Premiere. Penggabungan masing-masing gambar dari hasil layout CorelDraw dilakukan dengan menganut storyboard yang dibuat sebelumnya agar hasilnya sesuai yang direncanakan. Seperti penempatan gambar berdasarkan urutan, memberikan durasi pada gambar, menyisipkan video diantara gambar hingga menambahkan audio untuk lebih menghidupkan proses menyampaian informasi berupa video interaktif.

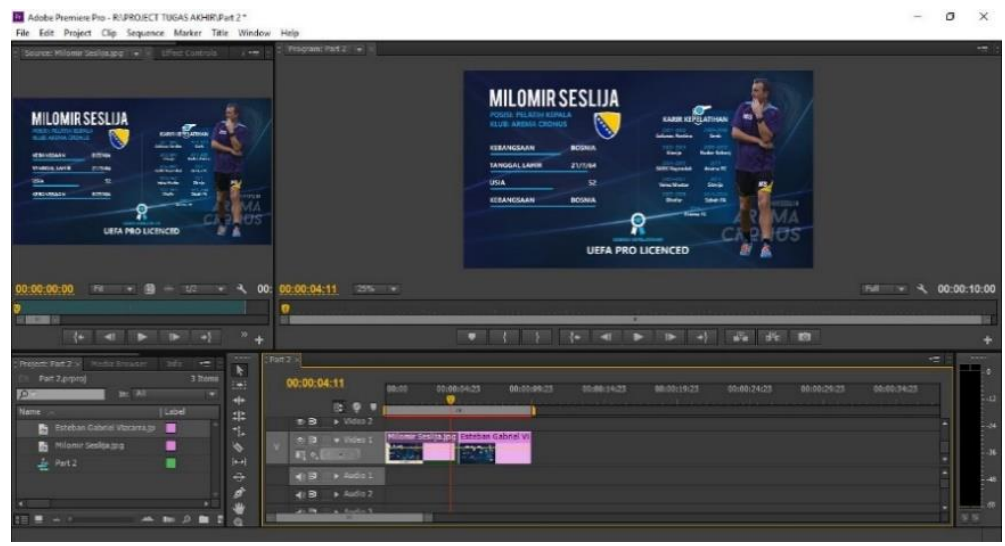

Gambar 12. Komposisi Adobe Premiere

Bahan berupa file gambar dari CorelDraw yang dimasukkan ke dalam akan sesuai dengan ukuran lembar kerja Adobe Premiere. Pengaturan awal pada CorelDraw akan mempermudah proses editing pada Adobe Premiere.

\section{Rendering}


Setelah proses penggabungan video, gambar dan audio selesai tersusun, selanjutnya adalah proses rendering. Rendering digunakan untuk menyempurnakan hasil sementara dari semua objek. Export file Adobe Premiere ke format MP4 dan menggunakan preset HD 1080p untuk mendapatkan video berkualitas tinggi.

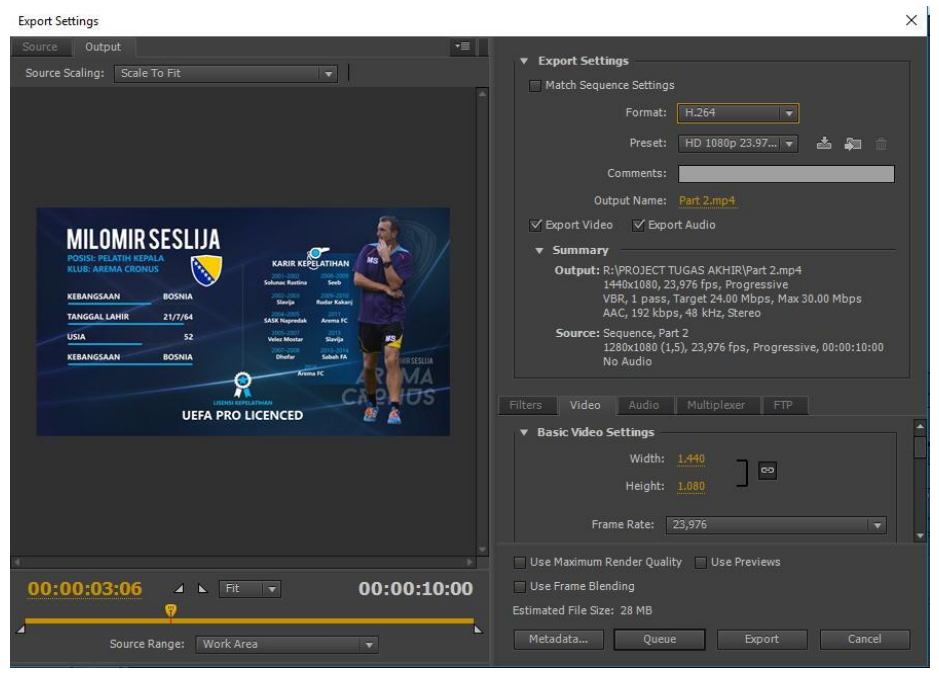

Gambar 13. Export Video

\section{Editing Youtube}

\section{Unggah Video}

Proses selanjutnya yang dilakukan setelah video hasil rendering Adobe Premiere, maka video tersebut di unggah ke web portal berbagi video atau yang lebih dikenal dengan Youtube.

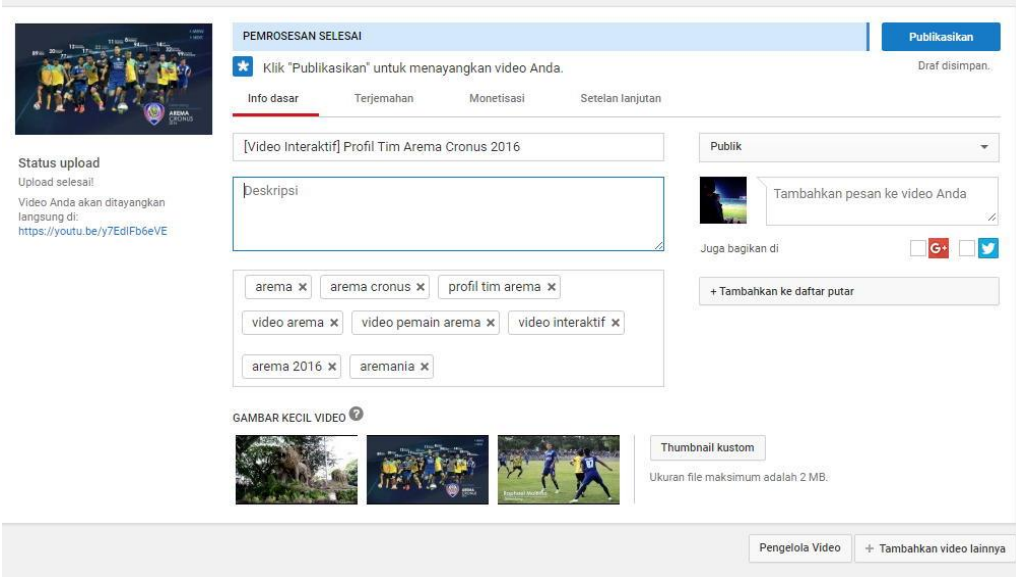

Gambar 14. Unggah Video Youtube 
Tunggu hingga proses unggah video selesai. Isi informasi dasar terkait video yang di unggah seperti judul, deskripsi, dan kata kunci untuk memudahkan pengguna menemukan video ini. Cari dan pilih gambar menarik yang bisa digunakan sebagai sampul video, ini dimaksudkan untuk memancing rasa ketertarikan pengguna agar menonton dan berinteraksi dengan video ini.

\section{Konfigurasi Anotasi}

Anotasi sendiri merupakan salah satu fitur yang disediakan Youtube untuk pengguna agar dapat memberikan tautan internal atau eksternal ke video lainnya. Selain dapat menautkan video lainnya, fitur ini memiliki kemampuan untuk menautkan atau berpindah ke durasi tertentu yang telah ditentukan dalam satu video.

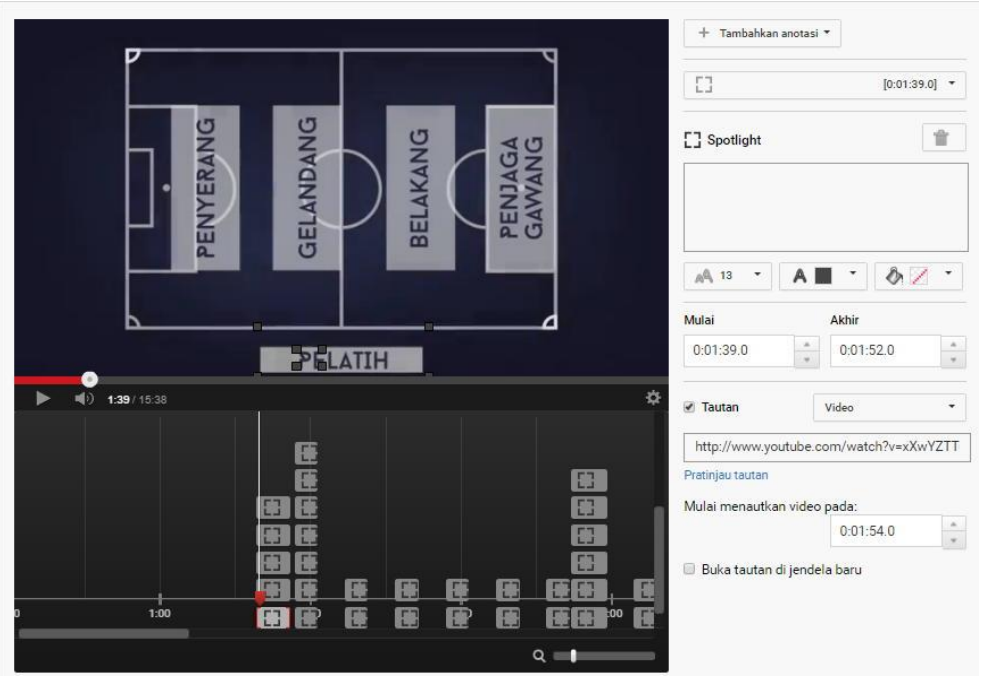

Gambar 15. Pengaturan Anotasi

Pada halaman fitur anotasi, diberikan objek pada video dan dapat melakukan konfigurasi pada panel sebelah kanan. Panel inilah yang akan menentukan sebuah video dapat menampilkan interaktif. Jumlah objek anotasi pada video bergantung pada banyaknya menu yang akan digunakan sebagai menu interaktif. Tata letak anotasi menyesuaikan dari hasil layout yang telah dibuat sebelumnya menggunakan CorelDraw.

\section{Pasca Produksi}

Tahapan ini membahas evaluasi mengenai penyebaran video interaktif profil tim Arema Cronus 2016 dengan proses upload yang nantinya akan diuji agar mendapatkan hasil yang tepat sesuai dengan distribusi video berdasarkan target audience.

\section{Pengujian}


Pengujian ini dilakukan untuk mengetahui projek video interaktif profil tim Arema Cronus 2016 sudah berjalan dengan baik tanpa terjadi kendala apapun dan memastikan telah sesuai dengan perancangan sebelumnya. Pengujian video interaktif ini dituangkan dalam bentuk kuesioner dan dibagikan tersebar melalui media sosial Instagram untuk menjaring peserta kuesioner secara lebih luas dengan latar belakang penggemar atau pendukung tim Arema Cronus. Melalui formulir pada website aremaday.com dengan mengajukan 13 pertanyaan dan 3 pertanyaan tidak termasuk dalam hitungan. Berikut ini merupakan tabel 4.1 yang menjelaskan 13 pertanyaan yang dituangkan dalam kuesioner.

Tabel 5. Kuesioner

\begin{tabular}{|c|c|}
\hline No. & Pertanyaan Kuesioner \\
\hline & Siapa nama Anda? \\
\hline & Berapa umur Anda? \\
\hline & Berdomisili dimanakah Anda? \\
\hline 1. & Apakah Anda mengetahui tentang video interaktif? \\
\hline 2. & Apakah Anda mengetahui tim Arema Cronus? \\
\hline 3. & Apakah menurut Anda ini sudah termasuk video interaktif? \\
\hline 4. & $\begin{array}{l}\text { Menurut Anda, apakah tampilan layout video interaktif profil tim Arema } \\
\text { Cronus ini cukup menarik minat Anda untuk menonton? }\end{array}$ \\
\hline 5. & $\begin{array}{l}\text { Apakah teks yang digunakan pada video ini sesuai dengan kemampuan } \\
\text { baca Anda? }\end{array}$ \\
\hline .6. & $\begin{array}{l}\text { Menurut Anda apakah foto pelatih dan pemain Arema Cronus } 2016 \\
\text { terlihat jelas? }\end{array}$ \\
\hline 7. & $\begin{array}{l}\text { Menurut Anda, apakah durasi video pembuka pada video interaktif } \\
\text { profil pemain dan pelatih Arema Cronus } 2016 \text { sudah tepat? }\end{array}$ \\
\hline
\end{tabular}




\begin{tabular}{|c|l|}
\hline 8. & $\begin{array}{l}\text { Menurut Anda, apakah penggunaan warna pada background sesuai } \\
\text { dengan warna khas Arema Cronus? }\end{array}$ \\
\hline 9. & $\begin{array}{l}\text { Menurut Anda, apakah penggunaan musik (audio) sudah sesuai dengan } \\
\text { video interaktif ini? }\end{array}$ \\
\hline 10. & $\begin{array}{l}\text { Apakah video interaktif ini sudah cukup menginformasikan tentang } \\
\text { profil tim Arema Cronus 2016? }\end{array}$ \\
\hline
\end{tabular}

\section{Penilaian Hasil Kuesioner}

Perhitungan kuesioner menggunakan pengukuran tiga interval, akan didapatkan jawaban yang tegas pada Nilai Hasil (NH), yaitu "Ya, Tidak dan Lainnya". Jawaban "Ya" menggunakan simbol "Y", jawaban "Tidak" menggunakan simbol "T", dan jawaban "Lainnya" menggunakan simbol "L".

Tabel 6. Nilai Hasil Kuesioner

\begin{tabular}{|c|c|c|c|c|c|c|c|c|c|c|}
\hline \multirow{5}{*}{ Responden } & \multicolumn{10}{|c|}{ Nilai Hasil Kuesioner } \\
\hline & & & & & & & & & $\mathrm{NH} 9$ & $\mathrm{~N}$ \\
\hline & & & & & & & & & & $\mathrm{H}$ \\
\hline & $\mathrm{NH}$ & $\mathrm{NH}$ & $\mathrm{NH}$ & $\mathrm{NH}$ & & $\mathrm{NH}$ & $\mathrm{NH}$ & $\mathrm{NH}$ & & 1 \\
\hline & 1 & 2 & 3 & 4 & NH 5 & 6 & 7 & 8 & & 0 \\
\hline R 1 & $\mathrm{Y}$ & $\mathrm{Y}$ & $\mathrm{Y}$ & $\mathrm{Y}$ & $\mathrm{T}$ & $Y$ & $\mathrm{~T}$ & $\mathrm{Y}$ & Y & $\mathrm{Y}$ \\
\hline $\mathrm{R} 2$ & $\mathrm{Y}$ & $\mathrm{Y}$ & $\mathrm{Y}$ & $\mathrm{Y}$ & $\mathrm{L}$ & $\mathrm{Y}$ & $\mathrm{L}$ & $\mathrm{Y}$ & $\mathrm{Y}$ & $\mathrm{L}$ \\
\hline R 3 & $\mathrm{Y}$ & $\mathrm{Y}$ & $\mathrm{Y}$ & $\mathrm{Y}$ & $\mathrm{Y}$ & $\mathrm{Y}$ & $\mathrm{Y}$ & Y & $\mathrm{Y}$ & $\mathrm{Y}$ \\
\hline $\mathrm{R} 4$ & $\mathrm{Y}$ & $\mathrm{Y}$ & Y & $\mathrm{Y}$ & $\mathrm{Y}$ & Y & $\mathrm{T}$ & $\mathrm{Y}$ & $\mathrm{T}$ & $\mathrm{Y}$ \\
\hline R 5 & $\mathrm{Y}$ & $\mathrm{T}$ & $\mathrm{Y}$ & $\mathrm{Y}$ & $\mathrm{Y}$ & $\mathrm{Y}$ & $\mathrm{Y}$ & $\mathrm{Y}$ & $\mathrm{Y}$ & $\mathrm{Y}$ \\
\hline R 6 & $\mathrm{~T}$ & $\mathrm{Y}$ & Y & $Y$ & $\mathrm{Y}$ & $\mathrm{Y}$ & $\mathrm{L}$ & $Y$ & $Y$ & $\mathrm{Y}$ \\
\hline R 7 & $\mathrm{Y}$ & $\mathrm{Y}$ & $Y$ & $\mathrm{~L}$ & $\mathrm{Y}$ & $\mathrm{Y}$ & $\mathrm{L}$ & $Y$ & $\mathrm{~L}$ & $\mathrm{Y}$ \\
\hline R 8 & $\mathrm{Y}$ & $\mathrm{Y}$ & $\mathrm{Y}$ & $\mathrm{Y}$ & $\mathrm{Y}$ & $Y$ & $Y$ & $Y$ & $\mathrm{~L}$ & $\mathrm{Y}$ \\
\hline R 9 & $\mathrm{Y}$ & $\mathrm{Y}$ & $Y$ & $Y$ & $\mathrm{~T}$ & $\mathrm{Y}$ & $\mathrm{Y}$ & $Y$ & $Y$ & $\mathrm{Y}$ \\
\hline R 10 & $\mathrm{~T}$ & $\mathrm{Y}$ & $Y$ & $Y$ & $\mathrm{Y}$ & $\mathrm{L}$ & $\mathrm{L}$ & $Y$ & $Y$ & $\mathrm{Y}$ \\
\hline R 11 & $Y$ & $Y$ & $Y$ & $Y$ & $Y$ & $Y$ & $\mathrm{~T}$ & $Y$ & $Y$ & $Y$ \\
\hline R 12 & $Y$ & $\mathrm{Y}$ & $Y$ & $Y$ & $Y$ & $Y$ & $Y$ & $Y$ & $Y$ & $\mathrm{Y}$ \\
\hline R 13 & $Y$ & $Y$ & $Y$ & $Y$ & $\mathrm{~T}$ & $Y$ & $Y$ & $Y$ & $Y$ & $Y$ \\
\hline R 14 & $Y$ & $\mathrm{Y}$ & $\mathrm{Y}$ & $\mathrm{Y}$ & $\mathrm{Y}$ & $Y$ & $Y$ & $\mathrm{~T}$ & $\mathrm{Y}$ & $Y$ \\
\hline R 15 & $\mathrm{Y}$ & $\mathrm{Y}$ & $\mathrm{T}$ & $Y$ & $\mathrm{Y}$ & $Y$ & $Y$ & $Y$ & $Y$ & $\mathrm{~L}$ \\
\hline R 16 & $\mathrm{Y}$ & $Y$ & $Y$ & $\mathrm{~T}$ & $Y$ & $\mathrm{Y}$ & $Y$ & $\mathrm{~T}$ & $\mathrm{Y}$ & $\mathrm{Y}$ \\
\hline R 17 & $Y$ & $\mathrm{Y}$ & $\mathrm{Y}$ & $Y$ & $\mathrm{Y}$ & $\mathrm{T}$ & $\mathrm{L}$ & $Y$ & $\mathrm{Y}$ & $\mathrm{Y}$ \\
\hline
\end{tabular}




\begin{tabular}{|c|c|c|c|c|c|c|c|c|c|c|}
\hline R 18 & $\mathrm{~T}$ & Y & Y & Y & $\mathrm{T}$ & Y & $\mathrm{L}$ & Y & $\mathrm{T}$ & $\mathrm{Y}$ \\
\hline R 19 & $\mathrm{Y}$ & $Y$ & $Y$ & $Y$ & $\mathrm{Y}$ & $\mathrm{Y}$ & $Y$ & $\mathrm{~T}$ & $Y$ & $Y$ \\
\hline R 20 & $\mathrm{~T}$ & $Y$ & $Y$ & $\mathrm{~T}$ & $\mathrm{Y}$ & $\mathrm{T}$ & $\mathrm{L}$ & $Y$ & $Y$ & $Y$ \\
\hline R 21 & $\mathrm{Y}$ & $\mathrm{Y}$ & $\mathrm{Y}$ & $\mathrm{T}$ & $\mathrm{L}$ & $\mathrm{Y}$ & $\mathrm{Y}$ & $\mathrm{Y}$ & $\mathrm{L}$ & $\mathrm{Y}$ \\
\hline R 22 & $Y$ & $Y$ & $Y$ & $Y$ & $\mathrm{Y}$ & $Y$ & $\mathrm{~T}$ & $Y$ & $Y$ & $Y$ \\
\hline R 23 & $Y$ & $Y$ & $Y$ & $Y$ & $Y$ & $\mathrm{~T}$ & $\mathrm{~T}$ & $Y$ & $\mathrm{~T}$ & $Y$ \\
\hline R 24 & $\mathrm{~T}$ & $Y$ & $Y$ & $Y$ & $\mathrm{~T}$ & $\mathrm{~L}$ & $Y$ & $\mathrm{~L}$ & $Y$ & $Y$ \\
\hline R 25 & $\mathrm{~T}$ & $\mathrm{Y}$ & $Y$ & $\mathrm{~L}$ & $\mathrm{Y}$ & $\mathrm{Y}$ & $\mathrm{T}$ & $\mathrm{Y}$ & $\mathrm{Y}$ & $Y$ \\
\hline R 26 & $Y$ & $Y$ & $Y$ & $Y$ & $\mathrm{~T}$ & $Y$ & $\mathrm{~L}$ & $Y$ & $\mathrm{Y}$ & $Y$ \\
\hline R 27 & $\mathrm{~T}$ & $Y$ & $Y$ & $Y$ & $Y$ & $Y$ & $\mathrm{Y}$ & $\mathrm{Y}$ & $\mathrm{T}$ & $Y$ \\
\hline R 28 & $Y$ & $Y$ & $Y$ & $Y$ & $Y$ & $Y$ & $Y$ & $\mathrm{~T}$ & $\mathrm{Y}$ & $Y$ \\
\hline R 29 & $Y$ & $Y$ & $Y$ & $Y$ & $\mathrm{Y}$ & $\mathrm{T}$ & $Y$ & $Y$ & $\mathrm{Y}$ & $Y$ \\
\hline R 30 & $\mathrm{~T}$ & $\mathrm{Y}$ & $\mathrm{Y}$ & $\mathrm{T}$ & $\mathrm{Y}$ & $\mathrm{Y}$ & $\mathrm{Y}$ & $\mathrm{Y}$ & $\mathrm{Y}$ & $Y$ \\
\hline R 31 & $Y$ & $Y$ & $Y$ & $Y$ & $\mathrm{Y}$ & $Y$ & $\mathrm{~T}$ & $Y$ & $\mathrm{~T}$ & $Y$ \\
\hline R 32 & $\mathrm{~T}$ & $Y$ & $Y$ & $Y$ & $\mathrm{Y}$ & $\mathrm{Y}$ & $\mathrm{L}$ & $\mathrm{Y}$ & $\mathrm{T}$ & $Y$ \\
\hline R 33 & $Y$ & $Y$ & $Y$ & $Y$ & $\mathrm{~T}$ & $\mathrm{Y}$ & $Y$ & $Y$ & $Y$ & $Y$ \\
\hline R 34 & $\mathrm{~T}$ & $\mathrm{Y}$ & $\mathrm{Y}$ & $\mathrm{Y}$ & $\mathrm{Y}$ & $\mathrm{T}$ & $\mathrm{T}$ & $\mathrm{Y}$ & $\mathrm{T}$ & $Y$ \\
\hline R 35 & $\mathrm{T}$ & $\mathrm{Y}$ & $\mathrm{Y}$ & $\mathrm{Y}$ & $\mathrm{Y}$ & $\mathrm{L}$ & $\mathrm{Y}$ & $\mathrm{Y}$ & $\mathrm{Y}$ & $\mathrm{Y}$ \\
\hline R 36 & $\mathrm{T}$ & $Y$ & $Y$ & $Y$ & $\mathrm{Y}$ & $\mathrm{L}$ & $\mathrm{L}$ & $\mathrm{Y}$ & $\mathrm{Y}$ & $Y$ \\
\hline R 37 & $Y$ & $Y$ & $Y$ & $\mathrm{~T}$ & $\mathrm{Y}$ & $Y$ & $Y$ & $Y$ & $Y$ & $Y$ \\
\hline R 38 & $\mathrm{Y}$ & $\mathrm{Y}$ & $\mathrm{Y}$ & $\mathrm{Y}$ & $\mathrm{Y}$ & $\mathrm{T}$ & $\mathrm{Y}$ & $\mathrm{Y}$ & $\mathrm{T}$ & $Y$ \\
\hline R 39 & $\mathrm{~T}$ & $\mathrm{Y}$ & $\mathrm{Y}$ & $\mathrm{Y}$ & $\mathrm{T}$ & $\mathrm{T}$ & $\mathrm{Y}$ & $\mathrm{Y}$ & $\mathrm{Y}$ & $\mathrm{Y}$ \\
\hline R 40 & $\mathrm{~T}$ & $\mathrm{Y}$ & $Y$ & $\mathrm{Y}$ & $Y$ & $\mathrm{Y}$ & $Y$ & $Y$ & $\mathrm{Y}$ & $Y$ \\
\hline $\begin{array}{c}\text { Total } \\
\text { Menjawab } \\
\text { "Tidak" (\%) }\end{array}$ & 35 & 2,5 & 2,5 & $\begin{array}{c}12, \\
5\end{array}$ & 20 & $\begin{array}{c}17 \\
5\end{array}$ & 20 & 10 & 20 & 0 \\
\hline $\begin{array}{c}\text { Total } \\
\text { Menjawab } \\
\text { "Lainnya" } \\
(\%)\end{array}$ & 0 & 0 & 0 & 5 & 2,5 & 10 & 25 & 2,5 & 7,5 & 5 \\
\hline $\begin{array}{c}\text { Total } \\
\text { Menjawab } \\
\text { "Iya" }(\%)\end{array}$ & 65 & $\begin{array}{c}97, \\
5\end{array}$ & $\begin{array}{c}97 \\
5\end{array}$ & $\begin{array}{c}82, \\
5\end{array}$ & 77,5 & $\begin{array}{c}72, \\
5\end{array}$ & 55 & 87,5 & 72,5 & $\begin{array}{l}9 \\
5\end{array}$ \\
\hline
\end{tabular}

Setiap pertanyaan memiliki nilai hasil presentase dan rata-rata. Perhitungan hasil presentase diatas menggunakan rumus berikut ini.

Nilai Persentase $=$ Jumlah Jawaban $\times 100$

Jumlah Responden 
Berdasarkan data hasil kuesioner dari 40 responden bahwa 97,5\% mengetahui tim Arema Cronus, sedangkan yang tidak mengetahui hanya 2,5\%. Pengujian produk untuk interaktif mengacu pertanyaan kuesioner nomor 3, dihasilkan 97,5\% menjawab "Iya" atau fitur interaktif berjalan dengan sesuai dan 2,5\% menjawab "Tidak".

Sedangkan pengujian untuk tampilan video interaktif ini dari 40 responden 82,5\% memberikan jawaban positif dan 5\% menjawab "Lainnya" dengan memberikan saran untuk tampilan video. Dari semua responden yang berpartisipasi dalam kuesioner, video interaktif ini sudah termasuk mengenalkan dan memberikan informasi tentang profil tim Arema Cronus 2016. Hasil nilai presentasinya 95\% menjawab "Iya" atau setuju dan 5\% menjawab "Lainnya".

Dari hasil rekapitulasi diatas di dapat angka rata-rata presentase jawaban "Iya" menghitung menggunakan software Microsoft Excel dengan rumus =AVERAGE(B4:K4), maka dihasilkan jawaban "Iya" adalah 78,75\%. Dan jika dihitung menggunakan skala 1-4 dengan rumus $=78,75 / 100 \times 4=3,15$. Maka dalam sistem penilaian video interaktif ini masuk dalam Nilai interval 76-80, dalam skala 3,33 (B+) dan masuk dalam Tingkat Keberhasilan yaitu "Baik" seperti yang bisa dilihat pada tabel 4.3.

Tabel 7. Sistem Penilaian Kurikulum 2013

\begin{tabular}{|c|c|c|c|}
\hline $\begin{array}{l}\text { Nilai Interval } \\
\quad(0-100)\end{array}$ & $\begin{array}{l}\text { Skala } \\
(1-4)\end{array}$ & Predikat & $\begin{array}{c}\text { Tingkat } \\
\text { Keberhasilan }\end{array}$ \\
\hline $80-100$ & 4 & $\mathrm{~A}$ & \multirow{2}{*}{ Sangat Baik } \\
\hline $81-85$ & 3,66 & A- & \\
\hline $76-80$ & 3,33 & $\mathrm{~B}+$ & \multirow{3}{*}{ Baik } \\
\hline $71-75$ & 3,00 & B & \\
\hline $66-70$ & 2,66 & B- & \\
\hline $61-65$ & 2,33 & $\mathrm{C}+$ & \multirow{3}{*}{ Cukup } \\
\hline $56-60$ & 2 & $\mathrm{C}$ & \\
\hline $51-55$ & 1,66 & C- & \\
\hline $46-50$ & 1,33 & $\mathrm{D}+$ & \multirow{2}{*}{ Kurang } \\
\hline $0-45$ & 1 & $\mathrm{D}$ & \\
\hline
\end{tabular}


Secara keseluruhan responden menyukai dan memahami informasi yang disampaikan dalam video interaktif profil tim Arema Cronus 2016 ini. Informasi yang ditampilkan bisa dipahami, begitu juga dengan tampilan video interaktif yang dapat membuat pengguna tertarik untuk menonton video ini. Selain itu, publik melalui kuesioner juga memberikan tanggapan atau saran positif yang bersifat membangun.

\section{KESIMPULAN}

Adanya video interaktif profil pemain dan pelatih Arema Cronus 2016 akan memberikan terobosan terbaru dalam penyampaian informasi data diri pelatih dan pemian Arema Cronus 2016 melalui web portal Youtube sebagai media publikasi dan interaktif. Sehingga memudahkan pengguna untuk mengakses informasi dengan cara memilih menu yang dibutuhkan. Selain lebih cepat, informasi yang disampaikan kepada penggemar akan efisien berupa penghematan waktu lebih besar dibandingkan dengan menggunakan media presentasi atau cetak. Untuk menyusun video interaktif dapat dilakukan menggunakan software Adobe Photoshop untuk proses mengedit atau menghilangkan background gambar pemain dan pelatih Arema Cronus 2016. CorelDraw untuk membuat dan menata layout yang dikombinasikan dengan gmbar hasil editing Adobe Photoshop. Software Adobe Premiere digunakan untuk memproses pembuatan video, mengatur dan menyusun file yang telah selesai dibuat pada panel Timeline.

Guna mengetahui tingkat keberhasilan video interaktif profil tim pemain dan pelatih Arema Cronus 2016 kepada pengguna atau penggemar tim Arema Cronus dilakukan dengan pengujian produk. Melalui formulir kuesioner yang tersedia di web portal www.aremaday.com/kuesioner memberikan tiga belas pertanyaan, tiga pertanyaan utama menanyakan data diri peserta kuesioner dan sepuluh pertanyaan membahas video interaktif profil tim pelatih dan pemain Arema Cronus 2016. Berdasarkan hasil kuesioner yang terdiri dari empat puluh peserta bahwa 97,5\% mengetahui tim Arema Cronus, mengacu pada pertanyaan kuesioner nomor 2. Pengujian produk untuk keberhasilan fitur interaktif dari pertanyaan nomor 3, dihasilkan 97,5\% yang berarti fitur interaktif berjalan dengan sesuai. Sedangkan dari segi tampilan video interaktif mencapai hasil $82,5 \%$ yang menandakan tampilan video interaktif sesuai minat pengguna untuk melihat. Dari hasil kuesioner dan perhitungan antara jawaban rata-rata "Iya" dan "Tidak", maka video interkatif profil tim 
pelatih dan pemain Arema Cronus 2016 jika dirumuskan menggunakan Microsoft Excel dengan rumus =AVERGAE(B4:K4), hasil jawaban "Iya" didapat 78,75\%. Jika dimasukkan kedalam perhitungan sistem penilaian kurikulum 2013, maka hasil 78,75\% masuk dalam tingkat keberhasilan yaitu "Baik".

\section{DAFTAR PUSTAKA}

Kusrianto, Adi. 2007. Pengantar Desain Komunikasi Visual. Yogyakarta. Andi. Pramono, Gatot. 2007. Aplikasi Compenent Display Theory. Jakarta. Pustekkom. Riyana, Cepi. Pedoman Pengembangan Multimedia Interaktif. Bandung. Universitas Pendidikan Indonesia. 2007.

Setiawan, Daniel Okta. 2011. Pembuatan Company Profil Windo Jaya Printing. Surabaya. STIKOM.

Siregar, Hendra Cipta. 2009. Perancangan Media Informasi Legenda Objek Wisata Alam Gunung Tangkuban Perahu. Bandung. Universitas Komputer Indonesia.

Supriyono, Rakhmat. 2010. Desain Komunikasi Visual Teori dan Aplikasi. Yogyakarta. Andi.

Susanto, Adi. 2013. Perancangan Film Dokumenter Permainan Tradisional Sunda. Bandung. Unikom.

Winata, Adi. 2013. Pengembangan Modul Interaktif Materi Apresiasi Puisi Dan Prosa Untuk Sekolah Menengah Kejuruan Wiratama Kotagajah. Lampung. Universitas Lampung.

Yoga, Raharjo Kresno. 2013. Pembuatan Buku Company Profile PT. Karya Jaya Lestari Sebagai Media Operasional Dan Inventaris Perusahaan. Surabaya. STIKOM. 